\title{
EKSPERIMEN MENINGKATKAN IDENTITAS KEWIRAUSAHAAN MAHASISWA DENGAN METODE BLACK BOX THINKING
}

\author{
Inaya Sari Melati, Universitas Negeri Semarang \\ inaya.sari@mail.unnes.ac.id \\ Nina Farliana, Universitas Negeri Semarang \\ ninafarliana@mail.unnes.ac.id \\ Raeni, University of Birmingham \\ xxr472@bham.ac.uk
}

\begin{abstract}
ABSTRAK
Penelitian ini bertujuan untuk meningkatkan identitas kewirausahaan pada mahasiswa di matakuliah Kewirausahaan Fakultas Ekonomi Universitas Negeri Semarang. Metode penelitian yang digunakan dalam penelitian ini adalah kuasi eksperimen dengan penerapan Black Box Thinking yang dilaksanakan dalam treatment berupa Proyek Kewirausahaan selama 60 hari. Kelompok eksperimen dalam penelitian ini adalah mahasiswa di kelas internasional dan kelas reguler Jurusan Pendidikan Ekonomi yang sedang menempuh matakuliah Kewirausahaan. Data diuji dengan uji $\mathrm{T}$, meliputi: (1) Paired T-Test untuk mengetahui adakah perbedaan identitas kewirausahaan mahasiswa sebelum dan sesudah Proyek Kewirausahaan dijalankan, dan (2) Independent T-Test untuk mengetahui adakah perbedaan hasil pada kedua kelompok eksperimen. Hasil penelitian menunjukkan bahwa kedua kelas eksperimen mengalami kenaikan identitas kewirausahaan yang signifikan dan tidak ada perbedaan hasil diantara keduanya. Penelitian ini menyarankan perbaikan desain pengajaran di kelas kewirausahaan dengan mempertimbangkan desain bisnis mahasiswa yang berkelanjutan.
\end{abstract}

Kata Kunci: Black Box Thinking, identitas kewirausahaan, dan proyek kewirausahaan.

\begin{abstract}
This study aims to improve the entrepreneurial identity of students in the Entrepreneurship Course at the Faculty of Economic Universitas Negeri Semarang. The research method was a quasi-experimental method applicating the Black Box Thinking which was carried out in a treatment called the Entrepreneurship Project for 60 days. The experimental groups in this study were students in the international class and regular class at Department of Economic Education who were taking Entrepreneurship courses. Data were tested by T-Test, including: (1) Paired T-Test to determine whether there were differences in entrepreneurial identity of students before and after the treatment was run, and (2) Independent TTest to find out whether there were differences in the results of two experimental groups. The results showed that the two experimental classes experienced a significant increase in entrepreneurial identity and there
\end{abstract}


were no differences in the results between two groups. This study suggests improving the design of teaching in the entrepreneurship class by considering the design of a sustainable student business.

Keywords: Black Box Thinking, entrepreneurship identity and entrepreneurship project.

\section{PENDAHULUAN}

Setiap individu pada umumnya memperoleh kesadaran kewirausahaan (entrepreneurial awareness) melalui pengamatan binis orang lain sebelum benar-benar menjalankan bisnis untuk diri mereka sendiri. Namun, tidak banyak individu yang berani menjadi wirausahawan karena berbagai pertimbangan. Salah satunya berkaitan dengan pemikiran identitas kewirausahaan. Setiap identitas yang terbentuk pada diri seseorang berasal dari ekspektasi pribadinya sendiri yang kemudian didefinisikan melalui keyakinan yang bervariasi. Identitas kewirausahaan dibentuk dari waktu ke waktu dari pengalaman di masa lalu, dari perilaku yang diamati, dan dari kenyamanan yang ditimbulkan dalam suatu kelompok sosial (Burke, 2003).

Erikson merupakan ahli yang pertama kali menyajikan teori yang cukup komprehensif dan provokatif tentang perkembangan identitas diri .Teori Erikson dikenal juga sebagai "ego psychology" yang menekankan pada konsep bahwa "diri (self)" diatur oleh ego bawah sadar/unconcious ego serta pengaruh yang besar dari kekuatan sosial dan budaya di sekitar individu (Muus, 1996). Ego bawah sadar ini menyediakan seperangkat cara dan aturan untuk menjaga kesatuan berbagai aspek kepribadian serta memelihara individu dalam keterlibatannya dengan dunia sosial, termasuk menjalankan tugas penting dalam hidup yakni mendapatkan makna dalam hidup.

Erikson and Cremers (1989) menyatakan bahwa identitas diri melibatkan tujuh dimensi,antara lain: (a) Subyekif, Berdasarkan Pengalaman Individu yakni bahwa individu dapat merasakan suatu perasaan kohesif atau pun tidak adanya kepastian dari dalam dirinya, (b) Genetik, Hal ini bekaitan dengan suatu sifat yang diwariskan oleh orang tua pada anaknya, (c) Dinamis, Proses ini muncul dari identifikasi masa kecil individu dengan orang dewasa yang kemudian menarik mereka kedalam bentuk identitas baru yang sebaliknya, menjadi tergantung dengan peran masyarakat bagi remaja, (d) Struktural, Hal ini terkait dengan perencanaan masa depan yang telah disusun oleh remaja, atau dengan kata lain remaja telah mempersiapkan kehidupan di masa depannya, (e) Adaptif, perkembangan identitas remaja dapat dilihat sebagai suatu hasil atau prestasi yang adaptif. Identitas adalah penyesuaian remaja mengenai keterampilan-keterampilan khusus, kemampuan, dan kekuatan kedalam masyarakat dimana mereka tinggal, (f) Timbal balik Psikososial, Menekankan hubungan timbal balik antara remaja dengan dunia dan masyarakat sosialnya, dan (g) Status Eksistensial, bahwa remaja mencari arti dalam hidupnya sekaligus arti dari hidup secara umum.

Data interview yang diperoleh dari UNNES Entrepreneurship Center (UNSEC) menunjukkan bahwa pada kelompok start-up, mahasiswa mengalami krisis identitas untuk memulai kembali bisnisnya apabila bisnis yang sebelumnya telah dijalankan mengalami kebangkrutan. Untuk itulah diperlukan 
sebuah pendekatan baru untuk menguatkan identitas sebagai wirausaha pada diri mahasiswa sehingga mahasiswa mampu bangkit dan memperbaiki bisnisnya pasca kebangkrutan, baik dengan bisnis di bidang yang sama maupun di bidang yang berbeda.

Dalam rangka mengatasi krisis identitas kewirausahaan pada mahasiswa, penelitian ini didesain dalam bentuk penelitian eksperimen. Merujuk dari penelitian Newbery et al. (2018), penelitian ini menggunakan instrumen berupa proyek kewirausahaan untuk mengumpulkan data dan menguji hipotesis. Sebelumnya Zulfiqar et al. (2018) melakukan penelitian serupa namun dengan variabel yang berbeda. Temuan penelitian tersebut nyatakan bahwa proyek kewirausahaan terbukti berpengaruh signifikan dan positif terhadap sikap dan niat wirausaha. Namun demikian, dalam penelitian tersebut juga ditemukan bahwa norma subjektif tidak berkontribusi terhadap niat wirausaha. Artinya, orang-orang dengan sifat menghindari resiko (risk averse) yang tinggi cenderung tidak mau mengambil risiko. Oleh karena itu, dibutuhkan cara untuk mengubah sikap mereka agar berani untuk berwirausaha. Penelitian ini berusaha menggali lebih dalam, apakah identitas wirausaha dapat juga distimulus dengan sebuah proyek kewirausahaan, seperti variabel sikap dan niat wirausaha dalam penelitian sebelumnya.

Proyek kewirausahaan yang akan dilakukan dalam penelitian ini berbeda dengan model simulasi permainan bisnis yang digunakan oleh Mawhirter dan Garofalo (2016) yang menggunakan permainan virtual di dalam komputer. Simulasi permainan bisnis dalam konsep proyek kewirausahaan ini akan dilakukan selama 60 hari di dunia nyata, dengan empat kali presentasi perkembangan dan kebijakan penjualan yang diterapkan untuk masing-masing kelompok. Pada saat presentasi masing-masing kelompok juga melakukan refleksi terhadap efektifitas keputusan-keputusan yang diambil selama seminggu yang telah. Kemudian, tiap-tiap kelompok merencanakan kembali apa yang akan dilakukan seminggu ke depan.

Proyek kewirausahaan yang telah dirancang tersebut kemudian dikemas dalam matakuliah Kewirausahaan. Mental yang ingin ditanamkan kepada mahasiswa melalui proyek ini adalah konsep berpikir dengan nama black box thinking. Black box thinking adalah cara berpikir yang menjadikan kesalahan sebagai kesempatan untuk belajar dari kesalahan itu sendiri untuk menghindari kesalahan yang sama di masa depan (Syed, 2015). Istilah black box thinking diambil dari black box (kotak hitam) yang ada di setiap pesawat dalam industri penerbangan. Ketika terjadi kecelakaan, black box merupakan satu benda penting yang diprioritaskan untuk dicari, karena di dalamnya terdapat informasi yang mampu memberikan gambaran nyata bagaimana kecelakaan pesawat tersebut dapat terjadi atau faktor apa yang menyebabkan kecelakaan itu terjadi.

Sebagian besar individu cenderung tidak ingin mengakui bahwa terkadang mereka melakukan kesalahan. Sikap tidak mengakui atau menghindar dari kenyataan bahwa dirinya telah melakukan kesalahan akan menutup peluang seseorang untuk belajar dari kesalahan yang telah dibuat. Sebaliknya, dengan cara berpikir black box thinking individu dituntut untuk dapat mengakui, mengenali, dan mengevaluasi kesalahannya, sehingga dapat ditemukan penyebab kesalahan tersebut terjadi. Dengan demikian, apabila 
kejadian yang sama terulang, maka individu tersebut mengetahui hal terbaik yang dapat dilakukan alih-alih melakukan kesalahan yang sama. Penerapan black box thinking dalam berwirausaha diduga dapat menstimuli mahasiswa untuk tidak menyerah dalam menghadapi kendala yang terjadi pada bisnisnya, atau bahkan ketika bisnisnya mengalami kegagalan. Sebaliknya, black box thinking akan mengajarkan mahasiswa untuk mengidentifikasi penyebab kegagalan, mengevaluasi, serta mengkonstruksi solusi dari permasalahan yang dihadapi dalam bisnis.

Terdapat tiga hal yang melatarbelakangi individu membuat keputusan dengan tidak menitikberatkan sebab dan akibatnya: keraguan bagaimana mengeksekusi keputusan tersebut, keengganan untuk mengeksekusi keputusan, dan ketidakpuasan dengan dinamika tim yang dimiliki (Ilonen et al., 2018). Syed (2015) menyatakan bahwa terkadang kesalahan adalah bagian dari proses "menemukan". Proses "menemukan" disini bermakna menemukan kesalahan untuk kemudian dianalisis dan diperbaiki agar tidak terjadi kesalahan yang sama di masa depan.

Penerapan teori identitas dalam kajian pendidikan kewirausahaan dan pembentukan proyek kewirausahaan dengan konsep black box thinking merupakan kebaruan (novelty) dalam penelitian ini. Selain itu instrumen pembantu berupa "Diary Observasi" (observational diary) dalam proyek kewirausahaan ini. Diary Observasi merupakan alat yang digunakan untuk mempermudah seseorang mengobservasi sebuah objek. Pada umumnya diary observasi digunakan pada praktikan di dunia medis dengan dua tujuan: sebagai pedoman praktikan dalam mempelajari suatu materi dan sebagai alat untuk mengevaluasi performa karyawan/tenaga medis (Govaerts et al., 2005). Namun demikian, Diary Observasi pada penelitian ini didesain untuk membantu mahasiswa yang sedang belajar berwirausaha dalam mengevaluasi setiap keputusan bisnis yang telah diambil, efektifitasnya, mengakui kesalahan yang telah diperbuat, dan menemukan cara untuk memperbaiki kesalahan tersebut.

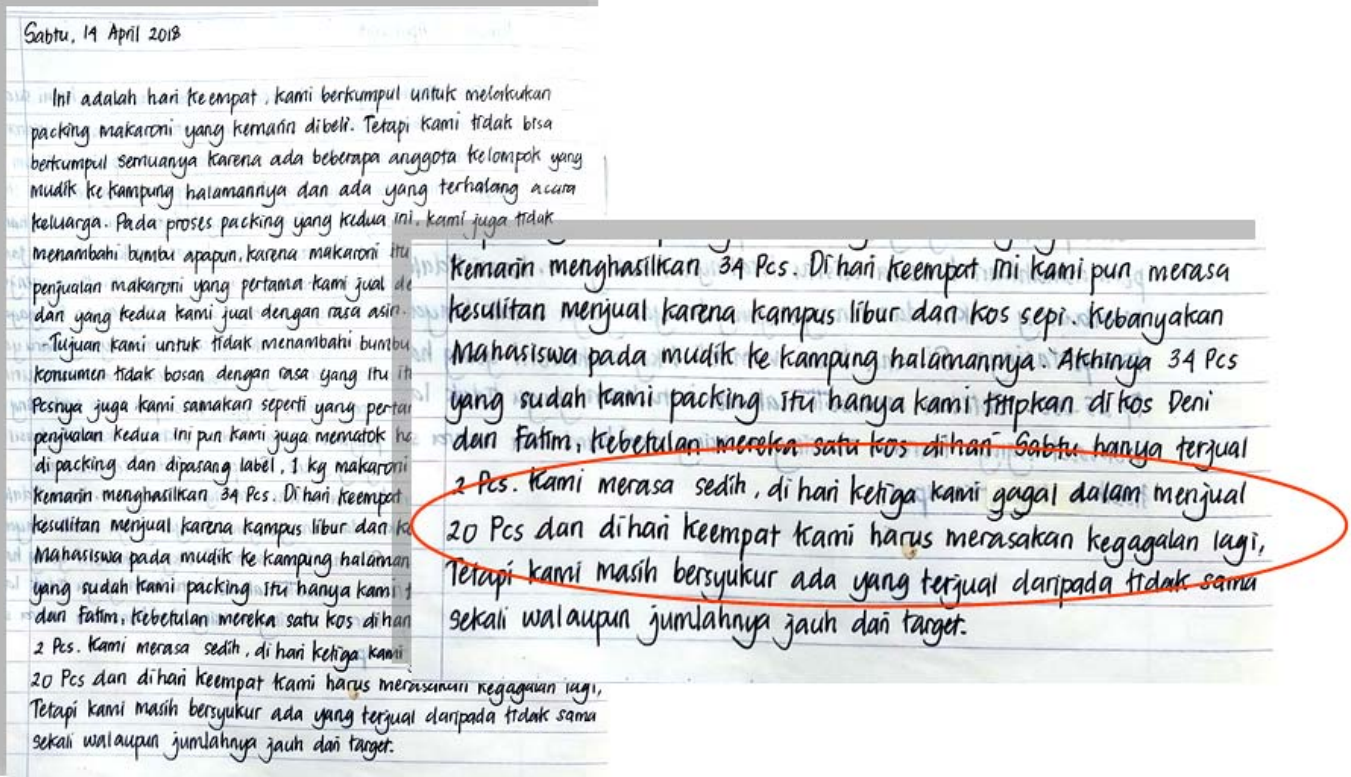

Gambar 1. Identifikasi Kegagalan Strategi dalam Diary Observasi 
Melalui cara ini, mahasiswa akan dilatih untuk tidak antipati terhadap kegagalan, melainkan justru menggunakan pengalaman gagal tersebut sebagai sumber belajar. Diary Observasi proyek kewirausahaan ini selanjutnya diberi istilah Diary Wirausaha dan bersifat individual, artinya setiap anggota kelompok kewirausahaan wajib menulis diary-nya sendiri.

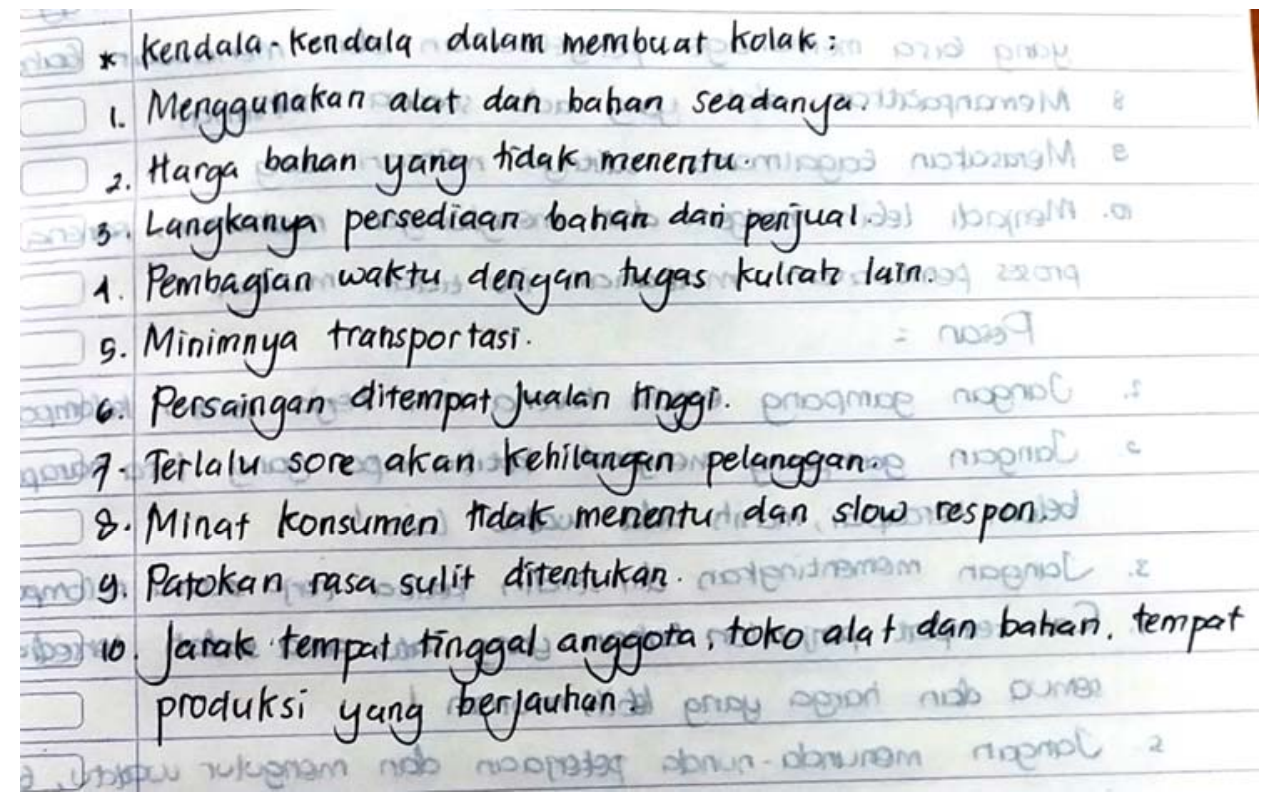

Gambar 2. Identifikasi Kendala yang Dihadapi dalam Proyek Kewirausahaan

Berlandaskan kajian teori identitas dan relevansinya terhadap pembentukan identitas kewirausahaan, proyek kewirausahaan dengan penerapan pola berpikir black box thinking dilengkapi instrumen pembantu berupa Diary diduga mampu membentuk identitas wirausaha mahasiswa di dalam matakuliah Kewirausahaan, sehingga hipotesis yang terbentuk berbunyi: "Terdapat kenaikan identitas wirausaha pada mahasiswa setelah diberi perlakuan berupa proyek kewirausahaan berkonsep black box thinking."

\section{METODE PENELITIAN}

Penelitian ini menggunakan model penelitian eksperimen semu (quasi experiment) dengan metode seri waktu. Desain penelitian eksperimen seri waktu hanya menggunakan satu grup yang dikenai satu atau lebih intervensi, kontrol yang digunakan adalah grup itu sendiri (Creswell 2015). Penelitian dilaksanakan di Universitas Negeri Semarang dengan objek mahasiswa pada matakuliah Kewirausahaan di Jurusan Pendidikan Ekonomi Fakultas Ekonomi. Sampel dalam penelitian ini adalah sejumlah 39 orang mahasiswa yang sedang menempuh matakuliah Kewirausahaan yang terbagi menjadi 2 kelas, 15 orang di kelas internasional dan 24 orang berasal dari kelas reguler. Pemberian treatment dan feedback dilakukan secara berulang sebanyak empat kali dalam jangka waktu 60 hari. Sebelum treatment dilakukan pre-test untuk mengukur identitas wirausaha. Setelah 60 hari dilakukan post-test dengan instrumen yang identik untuk mengetahui perbedaan hasil pada variabel tersebut. 
Instrumen penelitian yang digunakan berupa kuesioner berskala likert dengan 5 (lima) opsi yang terdiri dari 20 pertanyaan. Berdasarkan teori Erikson disusun 7 (tujuh) indikator identitas mahasiswa wirausaha yang meliputi: (1) Subyektif, pengalaman individu yakni mahasiswa dapat merasakan bahwa dirinya memiliki potensi untuk menjad wirausahawan yang sukses; (2) Genetik, histori pekerjaan orang tua dan keluarga mahasiswa; (3) Dinamis, histori keberhasilan dan kegagalan dari bisnis yang pernah dilakukan dan kiprah pada organisasi yang pernah diikuti; (4) Struktural, rencana usaha mahasiswa di masa depan; (5) Adaptif, prestasi yang pernah diraih berkaitan dengan kegiatan wirausaha; (6) Timbal balik Psikososial, hubungan mahasiswa dengan mahasiswa yang lain, dengan orang tua, dan dengan masyarakat; dan (7) Status Eksistensial, hal yang dilakukan mahasiswa untuk mewujudkan eksistensi diri.

Seluruh responden wajib mengikuti proyek kewirausahaan yang diadakan selama 8 kali pertemuan. Rincian kegiatan dapat dilihat pada Tabel 1. berikut.

Tabel 1. Kegiatan Pembelajaran sesuai Desain Black Box Thinking

\begin{tabular}{|c|c|c|}
\hline No. & Materi & Kegiatan \\
\hline 1 & $\begin{array}{l}\text { Penjelasan } \\
\text { pembelajaran }\end{array}$ & $\begin{array}{l}\text { Penjelasan dosen, pembagian kelompok kerja, penentuan } \\
\text { konsep produk yang akan ditawarkan pada konsumen. }\end{array}$ \\
\hline 2 & Pre-Test (Evaluasi 1) & $\begin{array}{l}\text { Mengukur trauma gagal bisnis dan identitas wirausaha } \\
\text { mahasiswa setelah mengalami berbagai kendala dalam } \\
\text { berwirausaha di masa lampau }\end{array}$ \\
\hline 3 & Praktik kewirausahaan 1 & $\begin{array}{l}\text { Mahasiswa menjual produk pada konsumen sesuai target } \\
\text { yang telah ditentukan }\end{array}$ \\
\hline 4 & Evaluasi 2 & $\begin{array}{l}\text { a. Identifikasi permasalahan yang dihadapi selama } \\
\text { melakukan Praktik Kewirausahaan } 1 \\
\text { b. Identifikasi penyebab permasalahan tersebut terjadi } \\
\text { c. Menyusun strategi untuk mengatasi setiap } \\
\text { permasalahan yang dihadapi }\end{array}$ \\
\hline 5 & Praktik kewirausahaan 2 & $\begin{array}{l}\text { Mahasiswa memperbaiki kesalahan pada praktik } \\
\text { kewirausahaan } 1 \text { dan mengimplementasikan strategi yang } \\
\text { telah ditentukan pada saat Evaluasi } 2\end{array}$ \\
\hline 6 & Evaluasi 3 & $\begin{array}{l}\text { a. Evaluasi keefektifan implementasi solusi } \\
\text { b. Identifikasi penyebab solusi tidak efektif (jika ada) } \\
\text { c. Identifikasi permasalahan baru yang dihadapi } \\
\text { d. Menyusun strategi untuk mengatasi setiap } \\
\text { permasalahan yang dihadapi }\end{array}$ \\
\hline 7 & Praktik kewirausahaan 3 & $\begin{array}{l}\text { Mahasiswa memperbaiki kesalahan pada praktik } \\
\text { kewirausahaan } 2 \text { dan mengimplementasikan strategi yang } \\
\text { telah ditentukan pada saat Evaluasi } 3\end{array}$ \\
\hline 8 & Post Test (Evaluasi 4) & $\begin{array}{l}\text { Mengukur trauma gagal bisnis dan identitas wirausaha } \\
\text { mahasiswa setelah mengalami berbagai kendala selama } 3 \\
\text { kali Praktik Kewirausahaan. }\end{array}$ \\
\hline
\end{tabular}

Sumber: desain penelitian eksperimen (tim penyusun, 2018)

Metode pengumpulan data dalam penelitian ini berupa kuesioner yang diisi pada saat pre-test dan post-test secara manual. Selain itu selama proyek kewirausahaan ini berlangsung, setiap individu diwajibkan untuk menulis segala kegiatan dan perasaannya dalam berwirausaha dalam sebuah Diary Observasi untuk mempermudah dalam analisis permasalahan dan solusinya. 
Analisis data dilakukan dalam dua tahap. Pertama, dianalisis perbedaan hasil treatment antara Kelas Reguler dan Kelas Internasional dengan independent t-test untuk mengetahui apakah terdapat perbedaan hasil pre-test maupun post-test keduanya. Uji ini menggunakan besaran alpha 0,05 dengan tingkat validitas data $95 \%$, maka apabila skor Sig. pada hasil olah data menunjukkan skor di bawah 0,05 dapat diartikan bahwa terdapat perbedaan pada kedua kelas eksperimen, dan sebaliknya apabila skor Sig di lebih besar dari 0,05 maka tidak terdapat perbedaan pada kedua kelas eksperimen. Selanjutnya dilakukan uji beda dengan paired t-test pada kedua kelas eksperimen untuk mengetahui perbedaan identitas wirausaha sebelum dan sesudah treatment dilakukan. Tidak berbeda dengan uji yang pertama (independent t-test), $u$ ji ini menggunakan besaran alpha 0,05 dengan tingkat validitas data 95\%, maka apabila skor Sig. pada hasil olah data menunjukkan skor di bawah 0,05 dapat diartikan bahwa terdapat perbedaan identitas wirausaha sebelum dan sesudah treatment pada kedua kelas eksperimen, dan sebaliknya apabila skor Sig di lebih besar dari 0,05 maka tidak terdapat perbedaan identitas wirausaha sebelum dan sesudah treatment pada kedua kelas eksperimen. Keda uji alam penelitian ini menggunakan alat bantu software IBM SPSS 19.

\section{HASIL PENELITIAN DAN PEMBAHASAN}

Hasil uji beda dengan menggunakan independent t-test pada kedua kelas responden menunjukkan bahwa kedua kelas eksperimen memiliki varians yang homogen dan tidak terdapat perbedaan hasil pre-test dan post-test diantara keduanya. Temuan ini menjadi referensi dalam penyusunan pembahasan. Pembahasan penelitian tidak akan membandingkan perbedaan perubahan variabel trauma gagal bisnis dan variabel identitas wirausaha antara kelas internasional dan kelas reguler, melainkan hanya berfokus pada perbedaan skor sebelum dan sesudah proyek kewirausahaan pada masing-masing kelas.

Tabel 2. Uji Beda Independen Kelas Internasional dengan Kelas Reguler

\begin{tabular}{cccccc}
\hline \multirow{2}{*}{ Variabel } & \multirow{2}{*}{ Tes } & \multicolumn{2}{c}{ Levene's Test } & \multicolumn{2}{c}{ T-test } \\
\cline { 3 - 6 } & & Sig. & Justifikasi & Sig. & Justifikasi \\
\hline Identitas & Pra & 0,146 & homogen & 0,833 & Tdk signifikan \\
\cline { 2 - 6 } Wirausaha & Post & 0,739 & homogen & 0,600 & Tdk signifikan \\
\hline
\end{tabular}

Sumber: data diolah (2018)

Berdasarkan hasil penelitian, diketahui bahwa identitas wirausaha pada kedua kelas eksperimen mengalami kenaikan yang signifikan. Kenaikan identitas wirausaha tersebut ditunjukkan dengan naiknya nilai rata-rata skor variabel indentitas wirausaha yang terdiri dari tujuh indikator yaitu: subjektif, genetik, dinamis, struktural, adaptif, psikososial, dan status eksistensial.

Hasil penelitian menunjukkan bahwa nilai rata-rata Identitas Wirausaha di Kelas Internasional sebelum dilaksanakan proyek kewirausahaan adalah sebesar 70, 67. Setelah mengikuti proyek kewirausahaan selama 60 hari dan kembali dilakukan tes dengan indikator yang sama, nilai rata-rata keseluruhan responden meningkat menjadi 75, 80. Terdapat peningkatan skor sebesar 5, 13 . 
Rincian perubahan nilai total masing-masing responden dapat dilihat pada Gambar 1.

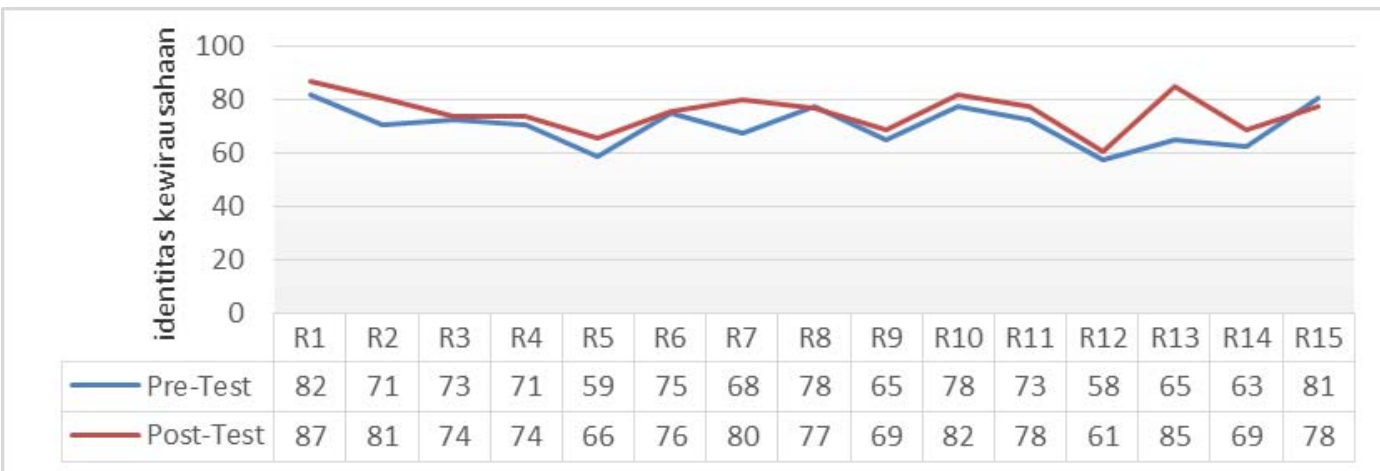

Gambar 3. Rerata Skor Identitas Kewirausahaan Kelas Internasional

Sumber: data diolah (2018)

Rincian perubahan per indikator Identitas Kewirausahaan sebelum dan sesudah proyek kewirausahaan dilakukan dapat diamati pada diagram batang di Gambar 2. Secara umum peningkatan skor identitas kewirausahaan dialami seluruh indikator. Perbedaaan skor yang paling besar terdapat pada indikator dinamis dan eksistensi.

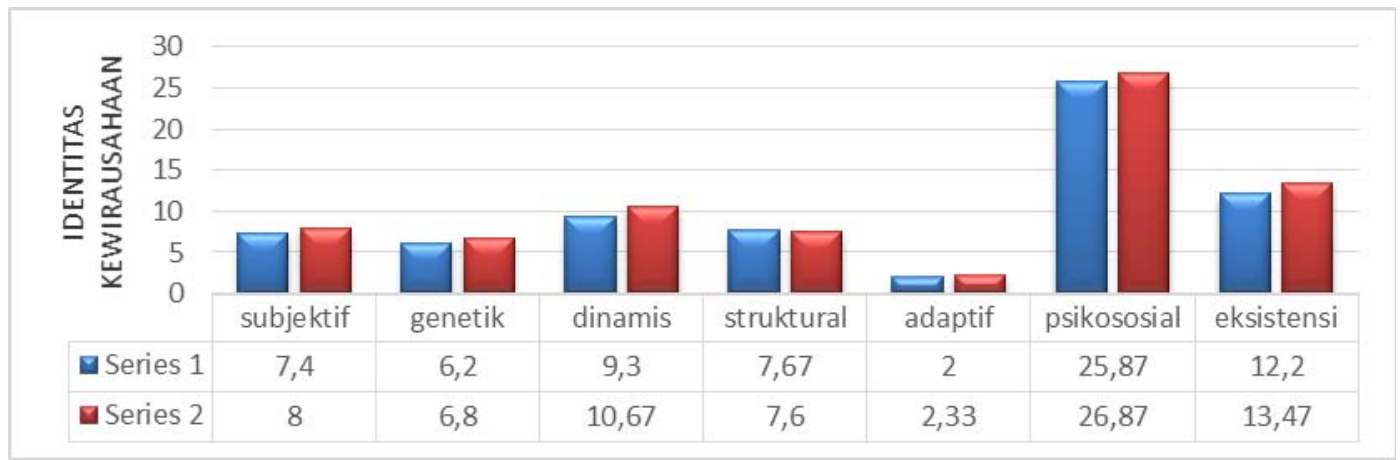

Gambar 4. Perubahan Skor Identitas Kewirausahaan per Indikator di Kelas Internasional

Sumber: data diolah (2018)

Hasil yang sama terjadi di Kelas Reguler, dimana setelah dilakukan proyek kewirausahaan selama 60 hari rerata total responden meningkat dari 71, 12 menjadi 74, 50. Peningkatan ini lebih kecil dari peningkatan yang terjadi di kelas internasional. Di kelas internasional, nilai rerata total meningkat sebesar 5,13 poin, sedangkan pada kelas reguler peningkatan poin hanya sebesar 3, 37 poin. Rincian skor pre-test dan post-test pada kelas reguler dapat dilihat pada Gambar 3. berikut.

Analisis lebih lanjut dilakukan untuk masing-masing indikator pada variabel identitas wirausaha untuk kelas reguler. Secara umum hampir seluruh indikator mengalami kenaikan, kecuali indikator faktor genetik dan faktor psikososial. Rincian perubahan nilai rata-rata untuk Identitas Kewirausahaan di Kelas Reguler dapat diamati pada Gambar 4. 


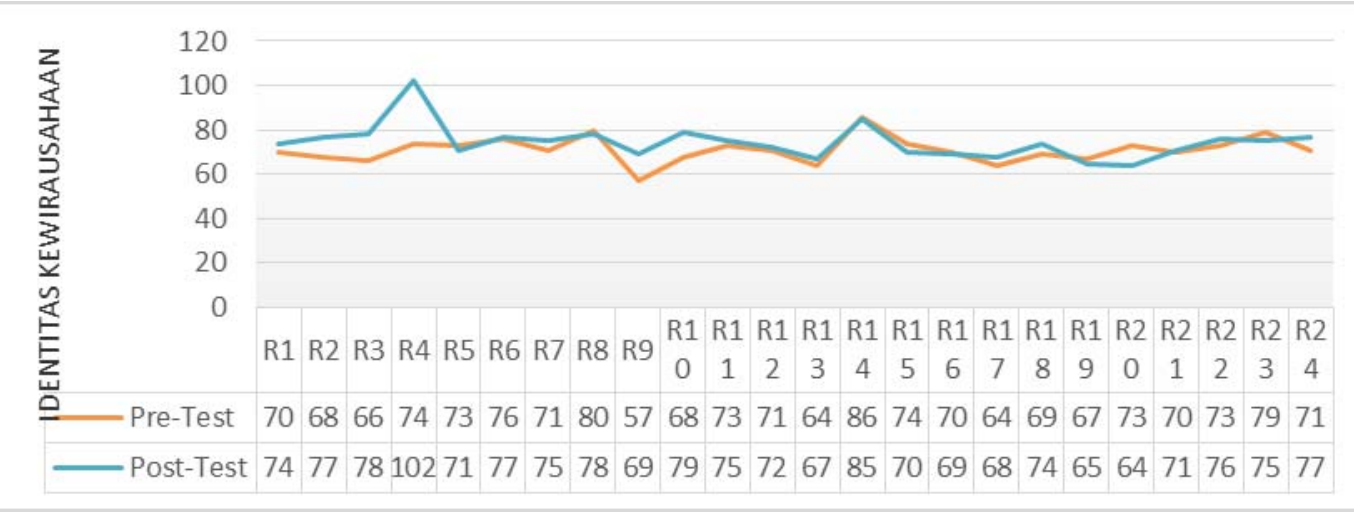

Gambar 5. Rerata Skor Identitas Kewirausahaan Kelas Reguler Sumber: data diolah (2018)

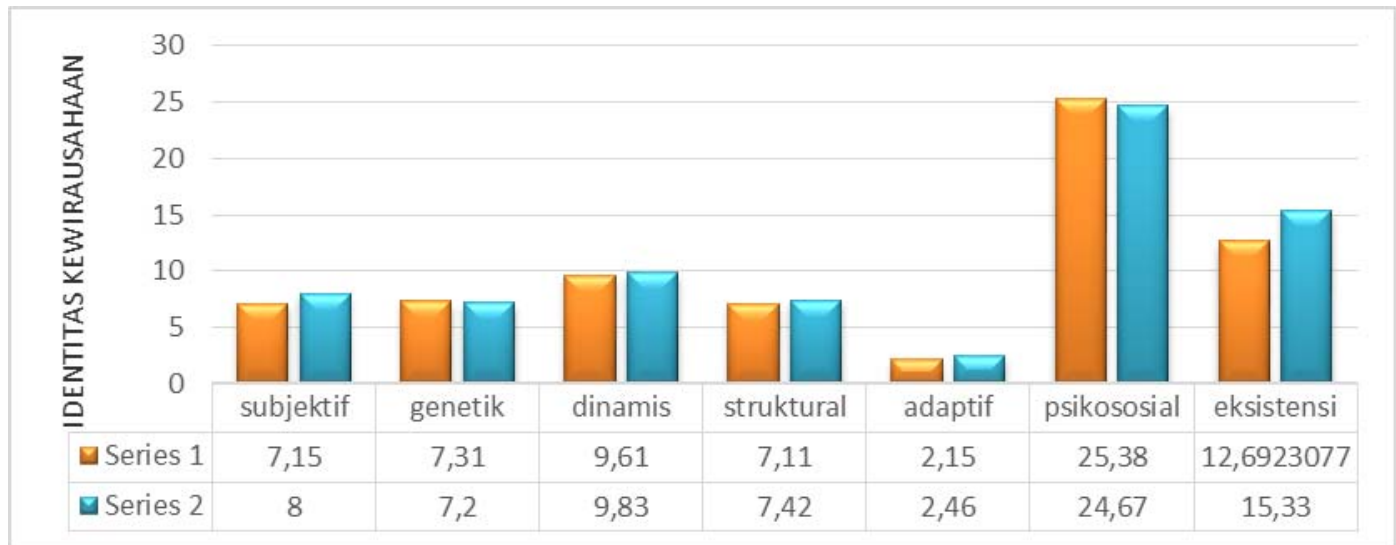

Gambar 6. Perubahan Skor Identitas Kewirausahaan per Indikator di Kelas Reguler Sumber: data diolah (2018)

Kenaikan terbesar terjadi pada indikator status eksistensial, sama seperti yang terjadi di kelas internasional. Status eksistensial berkaitan dengan seberapa bangga seorang individu menunjukkan kepada orang lain bahwa dirinya adalah seorang wirausahawan.

Berdasarkan hasil uji beda berpasangan yang dilakukan baik terhadap Kelas Internasional (KI) maupun Kelas Reguler (KR), keduanya menunjukkan perbedaan hasil yang signifikan antara sebelum dan sesudah proyek kewirausahaan dijalankan dengan konsep Black Box Thinking. Identitas Kewirausahaan responden naik secara signifikan sebesar 5,13 di Kelas Internasional dan 3,37 di Kelas Reguler. Hal ini menunjukkan bahwa Identitas Wirausaha dapat ditingkatkan dengan penerapan Black Box Thinking pada proyek kewirausahaan di Kelas Kewirausahaan berbantuan Diary Observasi. 
Tabel 3. Hasil Uji Beda Berpasangan Variabel Identitas Kewirausahaan

\begin{tabular}{ccccc}
\hline No. & Data Berpasangan & Mean & Std.Deviation & Signifikansi \\
\hline 1. & Pre-Test dan Post-Test KI & $-5,13$ & 5,64 & 0,003 \\
\hline 2. & Pre-Test dan Post-Test KR & $-3,37$ & 7,41 & 0,036 \\
\hline
\end{tabular}

Sumber: data diolah (2018)

Kedua kelompok eksperimen mengalami peningkatan identitas kewirausahaan pada aspek yang sama yaitu status eksistensial.Temuan tersebut mendukung dan melengkapi penjelasan bahwa proyek kewirausahaan yang dilakukan telah berhasil melatih mahasiswa melakukan proses black box thinking yang menghasilkan self-efficacy sehingga mereka semakin nyaman memposisikan diri sebagai wirausahawan. Dengan kata lain, identitas kewirausahaan mereka mengalami peningkatan.

Pertama, temuan yang dihasilkan dalam penelitian ini sesuai dengan teori identitas sosial Tajfel dan Turner (1979) dalam Buckingham et al. (2013) yang menyatakan bahwa identitas sosial adalah bagian dari konsep diri individu yang berasal dari keanggotaannya dalam satu kelompok sosial (atau kelompokkelompok sosial) dan nilai serta signifikasi emosional yang ada dilekatkan dalam keanggotaan itu. Identitas sosial dibangun melalui tiga tahapan yaitu identifikasi sosial, kategorisasi sosial, dan perbandingan sosial.

Menurut Tajfel dalam Hogg (2003) identifikasi merupakan identitas sosial yang melekat pada individu, mengandung adanya rasa memiliki pada suatu kelompok, melibatkan emosi dan nilai-nilai signifikan pada diri individu terhadap kelompok tersebut. Dalam melakukan identifikasi, individu dipacu untuk meraih identitas positif (positive identity) terhadap kelompoknya. Dengan demikian akan meningkatkan harga diri (self esteem) individu sebagai anggota kelompok. Sementara demi identitas kelompoknya, seseorang atau sekelompok orang rela melakukan apa saja agar dapat meningkatkan gengsi kelompok. Proses ini identik dengan yang dilakukan setiap kelompok selama Proyek Kewirausahaan. Hasil observasi dan hasil analisis dari Diary Observasi memperlihatkan bagaimana tiap-tiap kelompok berusaha mempromosikan dan menjual produknya masing-masing dengan cara yang kreatif dan mereka bekerja sama untuk melakukan kegiatan tersebut. Mereka juga melibatkan emosi dan setiap proyek yang dilakukan, hal ini tercermin dari Diary Observasi yang ditulis, beberapa kelompok menyampaikan bahwa selama proyek kewirausahaan banyak terdapat ketidakefektifan komunikasi dan kesalahpahaman sehingga sempat menimbulkan konflik dalam kelompok. Hal ini diperkuat dengan adanya beberapa kalimat bernada emosional juga terdapat di Diary Observasi.

Self categorization merupakan keikutsertaan diri individu secara spontan sebagai seorang anggota kelompok. Oleh karena itu dalam melakukan kategorisasi, terciptalah conformity, karena memungkinkan individu untuk mempertahankan identitas sosialnya dan mempertahankan keanggotaannya (Tajfel \& Turner dalam Hogg and Abrams, 1990). Dalam Proyek Kewirausahaan ini pada awalnya self categorization merupakan bagian dari setting proyek karena mahasiswa bekerja dalam kelompok. Namun demikian, pada perkembangannya dalam 60 hari, secara alamiah terbentuk 
pengkategorian yang lebih besar. Mahasiswa cenderung berinteraksi lebih sering dengan kelompok yang lain untuk saling membantu menyelesaikan permasalahan yang dihadapi terkait dengan proyek kewirausahaan, bahkan menjalin komunikasi dengan kelompok wirausaha yang lain di luar kelas.

Identitas sosial dibentuk melalui perbandingan sosial. Perbandingan sosial merupakan proses yang kita butuhkan untuk membentuk identitas sosial dengan memakai orang lain sebagai sumber perbandingan, untuk menilai sikap dan kemampuan kita. Identitas sosial terbentuk melalui penekanan perbedaan pada hal-hal yang terasa berbeda pada ingroup dan outgroup (Tajfel \& Turner, dalam Hogg \& Abrams, 1990). Dalam proyek kewirausahaan, mahasiswa melakukan perbandingan sosial antara satu kelompok dengan kelompok yang lain dengan mengevaluasi kinerja masing-masing kelompok (ingroup). Selain itu, mereka melakukan perbandingan dengan wirausahawan yang mereka anggap sebagai benchmark dan bahkan membandingkan diri dengan rekan sesama mahasiswa yang tidak melakukan kegiatan wirausaha (outgroup).

Kedua, temuan yang dihasilkan dalam penelitian ini didukung oleh beberapa penelitian yang relevan. Navis and Glynn (2011) mendefinisikan identitas kewirausahaan sebagai suatu klaim konstelasi antara pendiri, bisnis start-up, dan peluang pasar mengenai "siapakah kita" dan "apa yang kita lakukan" sebagai dasar penilaian investor tentang kemungkinan keberhasilan bisnis tersebut. Identitas Wirausaha merupakan faktor penting yang terlebih dahulu harus tertanam dalam diri sorang wirausahawan karena hal tersebut merupakan modal seorang wirausahawan untuk "menjual" baik ide bisnisnya kepada investor maupun produknya ke masyarakat.

Indikator status eksistensial yang mengalami peningkatan sebagai bagian dari identitas kewirausahaan meliputi bagaimana individu dengan percaya diri mampu memperkenalkan dirinya sebagai seorang wirausaha dan tidak ragu untuk mengekspos kegiatan kewirausahaannya. Hal ini sesuai dengan pendapat Giddens (1991) bahwa identitas adalah sebuah proses untuk menjadi sesuatu. Identitas tidak terletak dalam kepribadian individu, tetapi sebaliknya didasari oleh interaksi antara individu, masyarakat dan budaya. Dengan kepercayaan diri mahasiswa untuk melakukan sosialisasi dan pendekatan kepada target konsumennya, mahasiswa menjalin interaksi dengan individu maupun masyarakat pada umumnya dengan mempelajari budaya atau kebiasaan target konsumennya. Selama kegiatan tersebut berlangsung, proses internalisasi identitas kewirausahaan berjalan.

Kepercayaan diri yang tercermin dalam peningkatan status eksistensial sebelum dan sesudah proyek kewirausahaan mengimplikasikan peningkatan kepercayaan diri mahasiswa dalam menjalankan perannya sebagai wirausaha. Beberapa penelitian menyatakan bahwa kepercayaan diri wirausaha merupakan perubahan yang positif (apabila masih sesuai porsinya). Koellinger (2008) menemukan bahwa wirausahawan yang memiliki kepercayaan diri yang lebih memiliki kesempatan untuk menarik investor lebih banyak. Selain itu, wirausahawan yang lebih percaya diri dapat diharapkan untuk bertahan lebih lama dengan bisnisnya (Bernardo and Welch 2001). 


\section{SIMPULAN}

Temuan penelitian ini mengonfirmasi bahwa terdapat perbedaan yang signifikan pada identitas wirausaha mahasiswa setelah diberikan treatment berupa sebuah proyek kewirausahaan dengan metode Black Box Thinking. Baik mahasiswa yang berada di Kelas Internasional maupun di Kelas Reguler, keduanya mengalami peningkatan identitas kewirausahaan. Di sisi lain, tidak ada perbedaan yang signifikan antara perubahan skor di Kelas Internasional maupun Kelas Reguler. Hal ini menunjukkan bahwa proyek kewirausahaan dengan metode Black Box Thinking dapat diterapkan pada dua jenis kelas yang berbeda. Rekomendasi yang dapat diberikan untuk penelitian selanjutnya adalah perlunya desain proyek yang berkelanjutan, sehingga bisnis yang telah dibangun pada saat menempuh kelas Kewirausahaan tidak berhenti ketika semester berakhir, namun tetap berlanjut meskipun mahasiswa tidak lagi menempuh matakuliah Kewirausahaan.

\section{DAFTAR RUJUKAN}

Bernardo, A. E. \& Welch, I. 2001. 'On the evolution of overconfidence and entrepreneurs.' Journal of Economics \& Management Strategy, 10:3, 301-30.

Buckingham, S. A., Frings, D. \& Albery, I. P. 2013. 'Group membership and social identity in addiction recovery.' Psychology of Addictive Behaviors, 27:4, 1132.

Burke, P. J. 2003. 'Relationships among multiple identities.' Advances in identity theory and research: 195-214. Springer.

Creswell, J. W. 2015. 'Educational research: Planning, conducting, and evaluating quantitative and qualitative research, enhanced pearson eText with loose-leaf version--access card package.' Pearson Education, Inc.

Erikson, E. \& Cremers, A. 1989. Identitas dan siklus hidup manusia:(Bunga Rampai 1). PT Gramedia.

Giddens, A. 1991. Modernity and self-identity: Self and society in the late modern age. Stanford university press.

Govaerts, M. J., Van Der Vleuten, C. P., Schuwirth, L. W. \& Muijtjens, A. M. 2005. 'The use of observational diaries in in-training evaluation: student perceptions.' Advances in Health Sciences Education, 10:3, 171-88.

Hogg, M. A. 2003. Social identity. Guilford Press.

Hogg, M. A. \& Abrams, D. 1990. 'Social motivation, self-esteem and social identity.' Social identity theory: Constructive and critical advances, 28, 47.

Ilonen, S., Heinonen, J. \& Stenholm, P. 2018. 'Identifying and understanding entrepreneurial decision-making logics in entrepreneurship education.' International Journal of Entrepreneurial Behavior \& Research, 24:1, 5980.

Koellinger, P. 2008. 'The relationship between technology, innovation, and firm performance-Empirical evidence from e-business in Europe.' Research policy, 37:8, 1317-28. 
Mawhirter, D. A. \& Garofalo, P. F. 2016. 'Expect the unexpected: Simulation games as a teaching strategy.' Clinical Simulation in Nursing, 12:4, 13236.

Muus, R.1996. 'The contributions of Albert Bandura's social cognitive theory to an understanding of adolescence. In Theories of Adolescence', pp. 281-309.

Navis, C. \& Glynn, M. A. 2011. 'Legitimate distinctiveness and the entrepreneurial identity: Influence on investor judgments of new venture plausibility.' Academy of Management Review, 36:3, 479-99.

Newbery, R., Lean, J., Moizer, J. \& Haddoud, M. 2018. 'Entrepreneurial identity formation during the initial entrepreneurial experience: The influence of simulation feedback and existing identity.' Journal of Business Research, 85, 51-59.

Syed, M. 2015. Black Box Thinking: Why Most People Never Learn from Their Mistakes--But Some Do. Penguin.

Zulfiqar, S., Sarwar, B., Aziz, S., Ejaz Chandia, K. \& Khan, M. K. 2018. 'An Analysis of Influence of Business Simulation Games on Business School Students' Attitude and Intention Toward Entrepreneurial Activities.' Journal of Educational Computing Research, 0735633117746746. 


\title{
STRATEGI INVESTASI PADA RUMAH TANGGA PETANI \\ TRADISIONAL DI KECAMATAN MAPATTUNGGUL SELATAN
}

\author{
Yulhendri, Universitas Negeri Padang \\ yulhendriunp@gmail.com \\ Tri Kurniawati, Universitas Negeri Padang \\ trifeunp@gmail.com \\ Nora Susanti, STKIP PGRI Sumatera Barat \\ bundafyra@yahoo.co.id
}

\begin{abstract}
ABSTRAK
Menganalisis perilaku.

Kata Kunci: Investasi, Hari Tua, Konsumsi, Petani Tradisional.
\end{abstract}

\begin{abstract}
Analyzing

Keywords: Investment, Life Expectation, Consumption, Traditional Farmers.
\end{abstract}

\section{PENDAHULUAN}

Kecamatan Mapattunggul Selatan merupakan salah satu kawasan daerah terpencil di Kabupaten Pasaman. Masyarakatnya masih mengandalkan pola pertanian semi intensif dengan pola ladang berpindah dengan adopsi teknologi pertanian yang rendah. Akibatnya penduduk memiliki produktivitas dan pendapatan yang bisa dikategorikan rumah tangga miskin, Sanderson (2003).

\section{METODE PENELITIAN}

Penelitian ini dilaksanakan dari 3 Oktober hingga 1 Desember 2015 di

\section{HASIL PENELITIAN DAN PEMBAHASAN}

Secara geografis Kabupaten Pasaman dilintasi khatulistiwa dan berada pada 0055' Lintang Utara sampai dengan 0006' Lintang Selatan dan 99045'b Bujur Timur sampai dengan 100021' Bujur Timur. Ketinggian antara 50 meter sampai dengan 2.912 meter di atas permukaan laut. Secara administratif Kabupaten Pasaman terdiri dari 12 Kecamatan, dan 32 Nagari dengan luas wilayah $3.947,63 \mathrm{Km}^{2}$.

\section{SIMPULAN}


Berdasarkan data,

\section{DAFTAR RUJUKAN}

Boediono. 2005. Pengantar Ilmu Ekonomi No. 5 Ekonomi Moneter. Yogyakarta: BPFEYogyakarta.

Badan Pusat Statistik. 2015. Pasaman Dalam Angka: Lubuksikaping: BPS 


\title{
ANALISIS PENYEBAB
}

Rida Srihadiastuti, Universitas Telkom

rsrihadiastuti@gmail.com

Deden Syarif Hidayatullah, Universitas Telkom

dedensy@telkomuniversity.ac.id

\begin{abstract}
ABSTRAK
Program Wirausaha Baru

Kata Kunci: Lingkungan Keluarga, Kedisiplinan
\end{abstract}

\section{ABSTRACT}

Wirausaha Baru

Keywords: Business Failure, Entrepreneurship Training, New Business.

\section{PENDAHULUAN}

Mendapatkan pendidikan

\section{METODE PENELITIAN}

Metode yang digunakan

\section{HASIL PENELITIAN DAN PEMBAHASAN}

Sebagai gambaran awal tentang

\section{SIMPULAN}

Berdasarkan hasil penelitian

\section{DAFTAR RUJUKAN}

Alma, B. 2014. Pengantar Bisnis. Bandung: Alfabeta

Astamoen, Moko P. 2008. Entrepreneurship dalam Perspektif Kondisi Bangsa Indonesia. Bandung: Alfabera. 
